




\title{
A Imagética das Devoções Populares e os Espaços Sagrados no Semiárido Cearense
}

The imagery of popular devotions and sacred spaced in cearense semiarid

\author{
Ivo Luís Oliveira Silva ${ }^{1}$ \\ Gláudia Mota Portela Mapurunga ${ }^{2}$
}

1 Mestre em Avaliação de Políticas Públicas pela Universidade Federal do Ceará - UFC. Docente do Instituto Federal de Educação, Ciência e Tecnologia do Ceará, campus Canindé. E-mail: ivoluisos@gmail.com

2 Mestra em Gestão de Negócios Turísticos pela Universidade Estadual do Ceará - UECE. Docente do Instituto Federal de Educação, Ciência e Tecnologia do Ceará, campus Canindé. E-mail: glaudiamapurunga@gmail.com 


\section{Resumo}

A finalidade no presente trabalho não é fazer uma descrição detalhada da religiosidade popular, mas percorrer as sinuosidade dessa tradição, ressaltado as práticas de deslocamento, devoção e pagamento de promessa. A cidade escolhida foi Canindé, localizada no semiárido cearense, lugar de fervorosa devoção à São Francisco de Assis. A romaria é local de encontro com Deus e com o outro, gestos de solidariedade vão sendo construídos, espaços de socializações e trocas de experiências com o vivido são formados. Recorre-se a pesquisa bibliográfica, documental, diário de campo, etnografia e observação participante,empregado na tentativa de compreender os fenômenos sociais com suporte numa investigação mais próxima dos significados e comportamentos humanos. Dentre os resultados estão os romeiros que se acham eternos devedores da graça; a fé ligada no deslocamento; o pagamento da promessa para si e terceiros; sacralidade da festa e a religiosidade ligada a lógica do merecimento.

Palavras Chave: Espaços Sagrados. Catolicismo Popular. Peregrinações. Turismo Religioso.

\section{Abstract}

The purpose of this work is not to make a detailed description of popular regigiosity, but to go through the meanders of this tradition, highlighting the displacement practives, devotion and promises. The chosen city is Canindé, located in the cearense semiarid, a place of fervent devotion to Saint Francis of Assisi. The pilgrimage é meeting place with God and with others, gestures of solidarity are being built, spaces for socializations and exchange of experiences with the living are formed. We make use of bibliographical reasearch, field diary, ethnography and participative observation, using an attempt to understand social phenomena with the support of an investigation closer to meanings and human behaviors. Among the results are the pilgrims who are eternal debtors of grace; faith linked in displacement; promises for themselves and others; Sacredness of the party and religiosity linked to merit logic.

Keywords: Sacred Spaces. Popular Catholicism. Pilgrimages. Religious Tourism.

\section{INTRODUÇÃO}

A imaginação é um tanto admirável. Permite-nos pensar o mundo. Até mesmo quando nos remetemos para o passado, para um acontecimento vivido, recorremos à nossa imaginação. Uma quantidade de imagens submergem constantemente em nossas reflexões. Passado, presente e futuro são a matéria-prima de tudo o quanto nos completa.

Há uma caráter mediador nas imagens religiosas de devoções populares. Para Lopes (2010, p.9) as "imagens religiosas eram um poderoso veículo de mediação para as trocas 
sociais que Ela tanto incentivava". O objetivo desse ensaio é reconhecer nos espaços as sacralidades, representações, historicidades e significações a partir do elemento da fé.

O campo de observação é o município de Canindé3, localizado no Centro-Norte do Estado do Ceará, palco da maior romaria franciscana das Américas, com 2,5 milhões de pessoas e a segunda maior romaria franciscana do mundo. A mística no Santo de Assis envolve a cidade de tal forma que muitos chegam a acreditar, que São Francisco realmente viveu ou passou por essa cidade ${ }^{4}$.

Como percurso metodológico pratica o uso do registro em diário de campo, entrevistas informais, observações simples e participante, além da etnografia. As descrições dos lugares são construídos com recurso da memória individual e coletiva. A memória é tomada como elemento de diálogo e de valorização das lembranças "escondidas", por vezes, desapercebidas pelos pesquisadores.

A tentativa dessa produção é provocar reflexões do folclórico, cultural, religioso, social e institucional (Igreja Católica). Mantendo o distanciamento e a precisa observação sobre o material simbólico. Mergulhar no debate, concordando ou não, sobre a religiosidade popular. A aproximação de campo recai sobre a espacialidade e territorialidade simbólica.

\section{PERCURSO METOdOLÓGICO}

A pesquisa é de natureza qualitativa, leva em consideração a investigação histórica, descritiva, fenomenológica e etnográfica do município. Observando o romeiro encontramos, ao mesmo tempo, o visitante que se desloca pela cultura e lazer. Um turista que visita e não se anuncia, consome, mas não usa agenciamento, pernoita, mas não se hospeda e a "maioria de tudo que se oferece como um atrativo não passa de um ponto de ilusão em um mar de absurdos e agressões" (OLIVEIRA, 2007, p.17).

Fenômenos se exibem aos nossos olhos, embora nítidos precisam ser apreciados com maior prudência, desvelar o sentido deste que se mostra, para atingir o evento com maior intensidade. Lembremos que o mundo é realizado por intermédio dos nossos sentidos. A imagem, aqui, é um conceito "derivado da percepção cuja matéria prima é objeto físico externo" (MOREIRA, 2012, p.96).

O desafio é ultrapassar as externalidades dos acontecimentos, ir além daquilo que se vê, do que aparentemente se encontra em nossa frente. Teoricamente recorre-se a Frans Boas

3 A movimentação na cidade dar início em setembro, quando os romeiros aproveitam para agradecer ao Santo das Chagas. Aos poucos as romarias ganha corpo, peregrinos vão a pé, de bicicleta, caro, ônibus, motocicleta e pau de arara.

4 Essa afirmação parte do elemento folclórico e da memória coletiva advinda dos romeiros e devotos de São Francisco, uma afirmação com caráter folclórico e que faz parte do imaginário de Canindé, fruto de uma memória coletiva. 
(1858/1942) e Malinowski (1884/1942) inspiradores da pesquisa de cunho social. Reforça com Caleff (2006) no uso da etnografia. Concepções necessária para a análise do sagrado e profano, presentes em Rosendahl (2002). A autora debate para além do espaço, apresenta o elemento fé e tempo, a influência da religião sobre as pessoas; as significações da religião, território e territorialidade; as discussões sobre o lugar sagrado, percepção e simbolismo; a convergência e irradiação dos espaços sagrados uma menção às cidades-santuários.

Outros autores ampliam a discussão como Santos (1978) através do espaço como formação social; a relação homem-natureza de Quaini (1979) e a sociedade como natureza socializada.

Para Tuan (1983), lugar é o sentido do pertencimento, é a identidade do homem com os elementos do seu espaço vivido, cada objeto tem uma história que se confunde com a história do seus habitantes. Já Merleau-Ponty (1971) apresenta a dimensão da cultura dentro do espaço, as ideologias dominantes e as formas de resistências, a cultura como produto das relações sociais, orbitando entre elas a religião. E Durkheim (1989) mostra as elucidações da religião como prática naturalmente social, que se aproxima da coletividade. O espaço, sempre acompanhado da imagem, forma a diversidade de concepção que atravessa os diferentes campos gerais do pensamento. Além disso, diferentes autores complementaram nossas discussões.

\section{IMAGÉTICA DAS DEVOÇÕES NA HISTÓRIA DO BRASIL}

A relação com a imagem produz trocas sociais, culturais e religiosas, frutifica uma relação de sacralidade entre os materiais simbólicos e o simbolismo dos espaços vividos. E como isso ocorre? Por meio da devoção que é uma relação dialética entre o sujeito (ator da devoção) e os materiais (santo, andor, bandeira, água).

Na história do Catolicismo encontramos as configurações tradicionais ${ }^{5}$ de devoção católica, formas essas romanizadas de controle eclesiástico centralizadora e, na outra ponta, as novas expressões pressentes na religiosidade popular, que introduzem novas práticas, linguagens, gestos e rituais.

Lopes (2010) apresenta a existência da tensão entre a "mediação institucional da Igreja e as dinâmicas devocionais locais" (p.12). Já Maldonado (1986) adverte sobre a distinção entre o popular e o não popular, como se fossem somente a diferença entre o laico/clerical ou popular/erudito. Para o autor a religiosidade popular se configura

5 Em relação as imagens "não é uma relação exclusiva de uma religião, mas teve sua expressão histórica mais institucionalizada se reproduzindo no campo do cristianismo, sobretudo no catolicismo. (...) sob o controle da Igreja, mas que foram recriadas desde as experiências religiosas populares, originando uma forma de culto distinta da oficial: o culto dos santos". (LOPES, 2010, p. 41) 
como "a busca de relações mais simples, mais direta e mais rentável com o Divino" ( $p$. 401). Ou seja, relação carregada de dimensão emocional, espontânea, onde não caberia, essa racionalidade em busca do mais simples. Permita-nos, assim, discrepar de Brito $(1998$, p.103) que define popular como "oposição entre Igreja do povo e o clero (...) elaborada pelo povo em oposição a cultura erudita; nesse caso de cunho clerical".

Se uma imagem perde seu caráter de mediação, as próprias relações são capazes de produzir uma nova imagem e fazê-la figurada, ou ainda, de figurar, como no caso da reprodução do pau-de-arara, da imagem de exílio e retirante da seca para o transporte de fieis e romeiros. Então, qual o sentido da imagem? "A imagem traz uma evocação, lembrança, recordação, manifestação do sensível, do abstrato ou o invisível, semelhança ou relação simbólica" (LOPES, 2010, p. 21).

Eliade (1996), oferece uma compreensão sobre à sacralização de objetos, pessoas e lugares, a partir manifestação do transcendente denominado de hierofania, que é à própria revelação do sagrado e, apesar disso, continuar a ser ele mesmo. Existimos em uma sociedade de imagens, Elas se tornaram o estímulo de mediação das nossas relações. A imagem define o corpo ideal, a relação perfeita, comercializa produtos, estimula emoções, constitui padrões e induz vontades. Quem está suscetível a leitura das imagens? Aumont (1995, p. 197) profere que "a imagem só existe para ser vista por um espectador historicamente definido". E é "na memória e na imaginação(...) que se arranjam em sistemas portadores de significação" (FRANCASTEL, 1993, p.70).

Para Rosendahl (2002, p.16), "a palavra sagrado significa separação" e a definição, sugere a distinção entre o espaço comum de um lugar sagrado. O lugar sagrado não pode ser outro que não o lugar onde se encontram os símbolos. Para o entendimento sobre o espaço Milton Santos (1978) narra que "a utilização do território pelo povo cria o espaço", inabalável em seus limites apresenta transformações ao longo da história, o território antecede o espaço.

Yi Fu Tuan avalia que "os acontecimentos simples podem com o tempo se transformar em um sentimento profundo pelo lugar" (1983, p.158) e incorpora sentimentos de afeição, admiração por lugares e paisagens valorizadas. De acordo com Tuan o próprio caminhar adquire uma densidade de significado e uma estabilidade que são traços característicos do lugar." (1983, p. 200).

Assim, o devoto se apresenta por meio do deslocamento e fé. Não necessita da autoridade eclesiástica para cultuar seu Santo de devoção. Ele o escolhe e se sente eleito por ele e, com ele, cumpre uma sacralização simbólica da vida cotidiana. A religiosidade popular é profundamente mística. Cada sujeito social manifesta, com espontaneidade sua relação. "O espectador das imagens oscila regularmente entre a ação e a sujeição" (LOPES,2010, p.37). 
A partir da colonização da América pelos Ibéricos, podemos notar a importância da Igreja Católica na cristianização e na conquista espiritual dos indígenas a partir do século XV. Introduzindo forçosamente a religião no período colonial. À Igreja apresentava a dominância pelos sistema de Padroado. Espanha e Portugal obtiveram do papa Jus Patronatus, por diversas bulas papais, a Coroa tinha um controle na nomeação eclesiásticas, responsável pelo pagamento do clero que vinham para o Brasil ${ }^{6}$. O preceito do Padroado Régio definiam quais as Igrejas seriam erguidas e o nome de Santo padroeiro indicado comumente pelo donatário, detentor dos recursos para a edificação. Essa prática estabeleceu um modelo de catolicismo,em que os devotos são assentados sobre a proteção divina do Santo.

O padroado outorgava ao monarca a jurisdição eclesiástica sobre as terras colonizadas, garantindo liberdade de ação e autonomia do papado. A construção de igrejas, dioceses e paróquias, condução de bispos, prelados e padres eram definidas segundo à aprovação do Rei, a isso titulou de regalismo ${ }^{7}$, ou seja, a ingerência do domínio civil nos interesses eclesiástico (AZZI, 1978).

Para auxiliar nas responsabilidades de administrar política e religiosamente as colônias, o Rei de Portugal fundou a Mesa da Consciência e Ordens; e o Conselho Ultramarino que exerceram o papel determinante na estrutura da Igreja Católica Brasileira em formação, fazendo com que a estrutura não fossem subordinados à Sé Romana, mas sim às exigências do Regalismo (LOPES, 2010).

Assim, o padroado constitui uma dupla referência da organização institucional da Igreja Católica no Brasil. Ao obter do papado graças para que propagassem a fé e realizassem conquistas sobre os infiéis, garantiu condições para a implantação de uma estrutura eclesiástica na Colônia. À construção de igrejas demarcaram duplamente a presença de Deus e da Coroa (HOONAERT, 1983).

Hoonaert (1983) descreve que a evangelização colonial brasileira acompanha os preceitos oligárquicos, patriarcal, rural, escravista, de transmissão oral da fé e com uso de imagens sacras nas residências. Todo esse arsenal permitiu a transição da imagem institucionalizada da Igreja para um reflexo mais popular. Primeiras catequeses cristã emanada da casa-grande e dirigida à senzala, era de "responsabilidade muitas vezes foi confiada a um 'crioulo' ou ao feitor do engenho" (p.340). Durante o período colonial brasileiro à religião era um problema de Estado. "Às igrejas e as capelas são símbolos religiosos que

6 Em 1522, quando o papa Adriano conferiu a D. João III o título de grão-mestre da Ordem de Cristo transmitida hereditariamente aos sucessores. Entre os benefícios da Ordem estavam "jurisdição eclesiástica sobre as terras que haviam conquistado e que não pertenciam ainda a nenhuma diocese" (AZZI, 1978, p. 163). Como foi a Ordem de Cristo que "financiou" a viagem da descoberta, o rei de Portugal assume o governo imperial e eclesiástico da Colônia.

7 Para Azzi (1978) o padroado era a forma do "governo de Portugal exercer á sua função de proteção sobre a Igreja Católica, religião oficial e a única permitida na nação". (p.162) 
demarcam a conquista de um espaço que se torna cristão (LOPES, 2010, p. 91).

Durante os séculos XII e XIII quando a institucionalização do catolicismo ocidental encontra sua estrutura na centralização romana, ou seja, a canonização são monopolizadas pelo Papa o processo de beatificação era bem diferente dos dias atuais:

Até o século $\mathrm{XI}$, a canonização se dava por consenso. Os bispos encaminhavam proposta ao papa, expressando o desejo das perspectivas comunidades. é esta a origem do ditado Vox Populi , vox Dei: o consenso popular manifestava a vontade divina. (...) a isso se acrescentava o desejo, bem legítimo, de cada comunidade ter os seus santos, os mais milagrosos e mais poderosos, de modo que os túmulos deles fossem objetos de constantes romarias. belas igrejas eram construídas,e a cidade em volta se desenvolvia (AUGRAS 2005, p.22) apud (LOPES, 2010, P.70).

A tradição oral reproduziram e criaram narrativas sobre os Santos, exemplos de ensinamento das virtudes cristãs que, ao se difundirem foram incorporando tradições locais. Para Augras (2005), atualmente, o procedimento de canonização acompanha uma composição mais rígida e complexa. Seguido de um resumo biográfico, o catálogo das virtudes do Santo e a lista de seus milagres.

As igrejas edificadas a partir das devoções aos santos faziam expandir cidades à sua volta. Essa expansão estaria vinculada, historicamente, ao modelo de peregrinações que se formaram, em torno de devoções. Para garantir a expansão das ordens religiosas católicas pelo mundo, as imagens dos patronos foram levadas juntos com os missionários, e assim a história dos Santos e de seus milagres se miscigenaram com a história das devoções populares.

Deleuze (1988) nos brinda com a reflexão acerca do objeto de contemplação que se repete e não se altera, mas em algum momento, "muda alguma coisa no espírito que a contempla' (p.127). Reflexão do presente vivo e passado puro, esse último permanecido com a ajuda da memória8.

No Brasil a deficiência histórica de clérigos na ação de aparelhamento institucional da Igreja, tornou a produção do culto católico uma experiência realizada regularmente por leigos. Em geral, os leigos estabeleciam-se em torno de Confrarias e Irmandades, que contiveram papel na organização da fé, sobretudo na promoção dos cultos e devoções (AZZI, 1978).

Por meio da Proclamação da República ocorre oficialmente a separação ente a Igreja e o Estado, dar início ao movimento de Reforma do Catolicismo no Brasil e o crescimento dos seminários no país. Os devotos apropriam-se das brechas deixadas no campo religioso e redefinem o catolicismo romanizado, a partir da permanência do culto

8 Nota da Autoria - Muitos dos Santos canonizados pela Igreja nem se quer chegaram ser cultuados, enquanto que outros se tornaram aceitos como modelos de santidade e institucionalização dos cultos. 
aos Santos, combinando-os com as pratica sacramentais regulares (HOONAERT, 1983).

No conjunto de manifestações religiosas tradicionais há elementos residuais da nossa história. As imagens trazem consigo a experiência devocional, a relação mediadora, a reprodução de referencias religiosas, a construção materializada do sagrado, os valores simbólicos que ultrapassam os limites da religiosidade, a memória (coletiva e/ou individual) empregada como filtro da consciência, a interligação com a memória devocional e a tessitura com as relações visíveis e invisíveis da fé.

\section{ROMEIROS DE CANINDÉ}

O caminho remete ao símbolo da chegada e da partida. A peregrinação refaz a condição de discípulo, seguidores de Cristo, reescrevem o testemunho dos Santos ${ }^{9}$. Os cristãos põe-se em, caminho para relembrar a fé nos lugares que indicam a memória daqueles que morreram em nome de Cristo.

O devoto transcende os ritos oficiais, por meio do conhecimento popular e das experiências de mundo que surgem entre o fiel e o sagrado. A peregrinação não finaliza com a festa, porque existe no devoto a odisséia interior, por meio da ruptura do tempo e do espaço. Romaria que nasce com o propósito de agradecer ou solicitar ao Santo sua intervenção em uma causa (ver imagem 01 e 02).

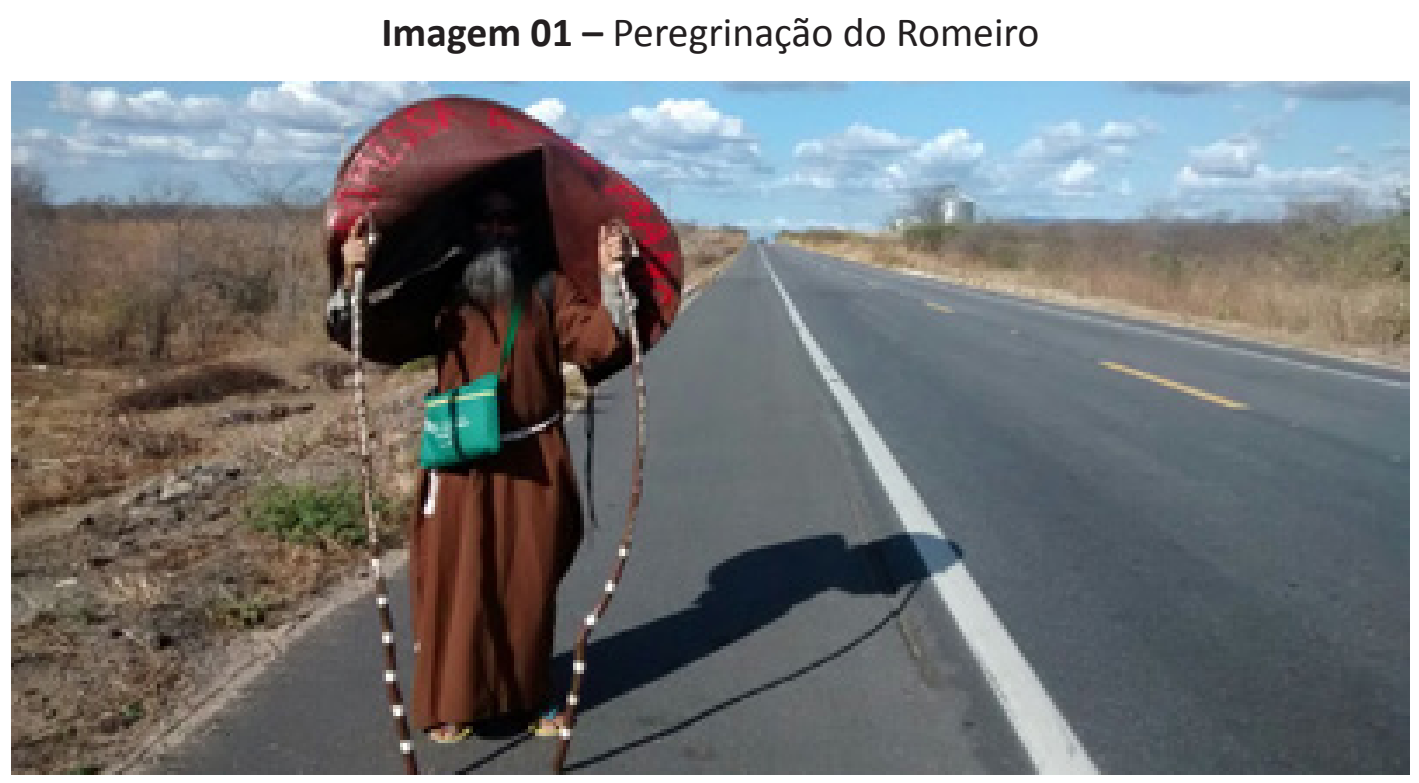

Fonte: Francelino Alves, 2014

9 Santos Mártires, Virgens, Contemplativos, Eremitas, Missionários, Doutores, Promotores de Justiça, Educadores, e de tantas nomeações. 


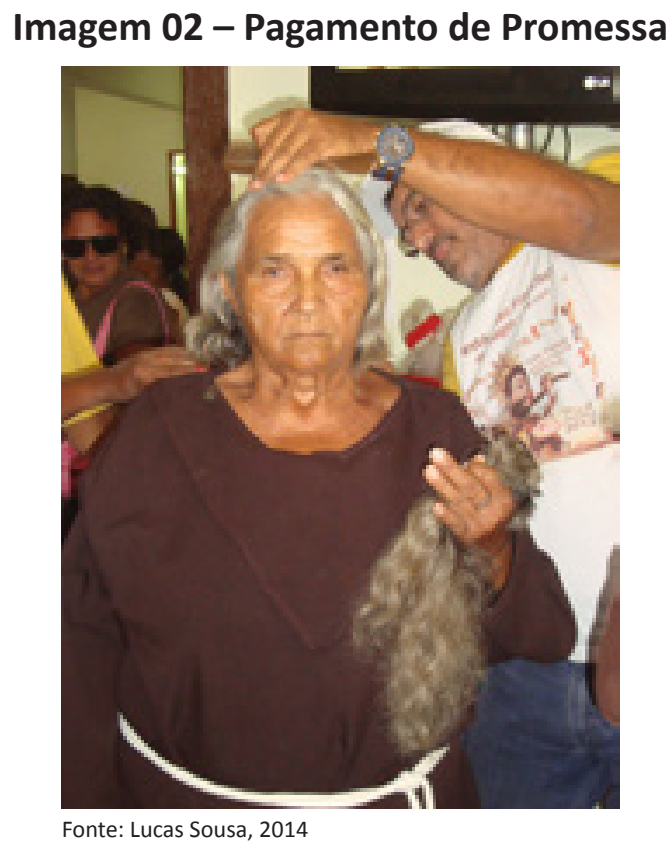

No movimento nascem os rituais. Para Turner(1974), os peregrinos, ao deixarem suas comunidades, seguem para o lugar sagrado, de onde esperam sair transformados, para logo em seguida reintegrar a sua comunidades de origem. Sobre Romaria Boff (1976) assegura que:

Catolicismo Popular, pelo fato de ser popular, está sempre relacionado com o Catolicismo oficial romano. As doutrinais fundamentais, os santos, os sacramentos, etc. são recebidos do Catolicismo oficial. Este o alimenta permanente, confere-lhe ou não legitimidade. Os próprios católicos do Catolicismo Popular se confessam dentro da Igreja oficial dos clérigos. Por isso não se pode entender o Catolicismo Popular sem a manutenção da dialética com o Catolicismo oficial. Este controla a palavra, mas deixa as práticas do povo bastante livres. (BOFF, 1976, p.50).

No trabalhos de Oliveira (2011) surgem as descrições sobre as romarias, representadas como: a) promessa, negócio, fidelidade, amizade e transcedencialismo das práticas religiosa. b) como penitência, sofrimento e "liberdade". c) como alienação, supervivência por meio da superação, transição do "pedido de graça"” para o "pedido de libertação". Em todas, julgamos apreciar a peregrinação como uma manifestação de fé que se expressa na espacialidade e no deslocamento de um lugar para o outro.

Canindé resguarda o maior santuário franciscano das Américas. Distante $110 \mathrm{~km}$ da capital, Fortaleza, a cidade é um dos pólos de romarias mais expressivos do Brasil. A concentração de fiéis movimentam a economia e o turismo religioso. Os festejos lideram a oferta de empregos indiretos, pois durante a celebração, aproximadamente, 2,5 milhões de devotos participam dos festejos, segundo a Assessoria de Romarias do Santuário São Francisco das Chagas de Canindé. 
A mística franciscana é tão surpreendente para quem observa, para muitos romeiros São Francisco viveu ou passou por aquela região ${ }^{10}$, fato comprovado nos relatos orais dos romeiros. A biografia oficial ${ }^{11}$ do Santo anunciar a descrição de um jovem italiano, de família abastada, que abandona tudo e vai servir ao chamado de Deus. Com uma vida de provações, sacrifícios e labor, é consagrado Santo pela Igreja Católica Romana. O período de maior movimentação de romeiros é entre 24 de Setembro a 04 de Outubro ${ }^{12}$, ocasião dedicada à memória do Santo.

O roteiro dessa pesquisa contempla a visitação a Basílica de São Francisco das Chagas, peregrinação a Via Sacra do Monte junto à Igreja de Cristo Rei, celebrações religiosas na Praça dos Romeiros, as orações na Casa dos Milagres e na Gruta de Nossa Senhora de Lourdes,em todos esses espaços contemplamos a divinização por parte dos romeiros ${ }^{13}$.

O santuário, em sua linguagem simbólica, faz memória ao lugar da presença divina, do encontro com Deus, da comunhão eclesial, do transcendentalismo, da espera pela Jerusalém celestial, do santuário escatológico gloriosa. Por detrás do espaço visível, há tantos outros invisíveis, edificados pelo homem por meio do imaginário social (GÓIS, 2009).

\section{INFERÊNCIAS DA PESQUISA DE CAMPO}

A religiosidade transporta consigo motivações devocionais, predominantemente, afetiva e sentimental. Permanece em nós uma tendência para identificar esta religiosidade como um elemento folclórico e/ou cultural. Perdendo com isso a presença do componente divino, sobrenatural e transcendental resididos na fé. O caminho do peregrino se faz com a condição da fé. Os romeiros se deslocam pelo cumprimento da promessas, do voto de fé e pela busca da bênção. A leitura que se faz sobre o cumprimento da promessa é a da retribuição do recebido.

As histórias, aqui, apresentadas são produtos de observações, registros etnográficos

10 Essa afirmação parte da cultura popular existente na cidade, advinda dos romeiros e devotos de São Francisco, uma afirmação com caráter folclórico e que faz parte do imaginário de Canindé, uma memória coletiva desses peregrinos.

11 Livro de Inácio Larrañaga, nominado O Irmão de Assis, é uma obra fascinante, que desvela o mistério de São Francisco, a profundidade de sua vida e a mensagem de amor.

12 No Santuário de São Francisco das Chagas de Canindé, as romarias se apresentam das mais diversas formas: a pé, de bicicleta, motocicleta, ônibus, pau-de-arara, a cavalo e tantas outras. Algumas romarias ganham destaque, pela organização e quantidade de fiéis. Segundo a Assessoria de Romarias e da Pastoral do Acolhimento do Santuário, a Moto-romaria de Fortaleza reúne aproximadamente 30 mil motoqueiros; a de Codó, do Maranhão, com 15 carretas e cerca de 2 mil fiéis; a romaria Comunidade Obreiros da Tardinha - COT, de Fortaleza, com aproximadamente 450 pessoas vindas a pé. Nos anos eleitorais, o Conselho Paroquial determina a alteração do calendário religioso, para que não conflite com o sistema eleitoral brasileiro.

13 O Governo do Estado em 2012, por meio da Secretaria do Turismo, construiu um trajeto composto por cinco estações, conhecido como Caminhos de Assis. Trata-se de um roteiro de peregrinação franciscana que parte da cidade de Maranguape e termina em Canindé. As obras custaram R\$ 1,2 milhão e conta com extensão de $136 \mathrm{~km}$. Nas estações, os romeiros encontram locais de recolhimento espiritual e descanso. 
e de diário de campo frutos da memória popular ${ }^{14}$. Na cidade de Canindé, alçamos alguns dos espaços sagrados, a mencionar como bens materiais: a Basílica de São Francisco das Chagas de Canindé, Gruta de Nossa Senhora de Lourdes, Casa dos Milagres, Zoológico de São Francisco, Museu Regional São Francisco, Estátua de São Francisco, Painel de São Francisco, Bandeira de São Francisco; e bens imateriais: Peregrinações, o Caminho de Assis, as fitas de São Francisco da Chagas, a Via Sacra e os Ex votos.

O primeiro espaço apresentado é a Basílica ${ }^{15}$ de São Francisco das Chagas de Canindé, local de romaria, orações, veneração, agradecimentos e penitências, de significativa importância para a comunidade cristã. Ir à Basílica é um ato de fé; local de júbilo e acolhimento. Como parte da promessa, alguns romeiros entram com as vestes franciscanas, na forma de mortalha (hábito) e na cintura uma corda; nas extremidades, três nós que representam a pobreza, castidade e obediência. Alguns procedem a promessa de joelhos até o altar-mor, outros perfazem circundado à Basílica. Os romeiros depositam suas ofertas em urnas como forma de agradecer as bênçãos recebidas. Nas laterais da Basílica, a imagem em tamanho natural de Jesus Morto e o Senhor carregando a cruz. Em ambas os fieis aproximam-se na tentativa de tocar, beijar, rezar e agradecer. $\mathrm{O}$ Santuário dispõem de relíquias ${ }^{16}$ para veneração, um serviço de acolhimento aos devotos de São Francisco (ver imagem 03).

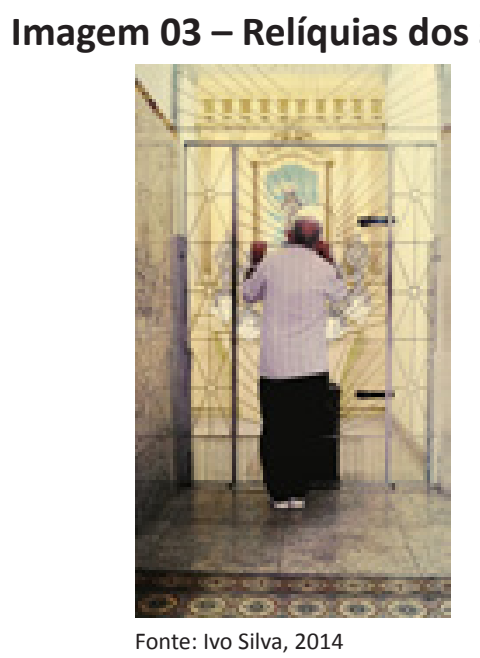

14 Memória do passado e a história do presente se entrelaçam no imaginário. O passado no presente dá sentido concreto nas narrativas orais ao afirmarem a sacralidade nas águas.

15 Edificada em estilo gótico-barroco, o templo tem altura de 25 metros (torre). Em 1925, foi elevada à categoria de Basílica Menor pelo Vaticano. É lugar sagrado para os romeiros, não somente pelo fato de reunir multidões para o culto, mas porque nesse espaço São Francisco revela para aqueles que acreditam.

16 No interior do Santuário, há para visitação as relíquias, que são objetos preservados para efeitos de veneração, sendo normalmente associados a objetos pessoais ou partes do corpo do santo. As relíquias são guardadas em receptáculos chamados relicários. Em Canindé, encontramos as relíquias de São Pedro, São Francisco, São Paulo e Santa Luzia. 
Na Casa dos Milagres ${ }^{17}$ uma intensa movimentação de peregrinos depositam seus ex votos, pedem informações ou adquirem itens religiosos. $O$ ex voto é representado na forma de membros humanos (perna, tronco, braço, cabeça), órgãos vitais (pulmão, coração, rim), casas, barcos, carros, motocicletas, fotografias, vestuários, mechas de cabelo, vestidos de noivas, roupas muletas, cadeira de roda, dentre tantos outros objetos confeccionados em madeira, gesso, linho, latão, papel, e todos simbolizam materialidade dos milagres ${ }^{18}$. Outro lugar de veneração é a Gruta Nossa Senhora de Lourdes, ponto de devoção mariana, localizado ao lado do Rio Canindé e à Casa das Velas.

$\mathrm{Na}$ Gruta, os fieis procuram na água a purificação do corpo e da alma, banham as mãos, a cabeça e os pés. Imergem fotografias, roupas, chaves e garrafas para coletar o bem para familiares e amigos. O lugar renovar a esperança de muitos, atribuem a cura sobrenatural de seus males a fé. $O$ espaço faz alusão à Nossa Senhora de Lourdes e une a devoção em São Francisco. A Casa das velas é uma sala para cumprimento de preces, lá os fiéis rogam a intervenção divina e transporta na vela o simbolismo da rogação. A vela acessa remete a imagem da consumação, iluminação da trevas, sacrifício de Cristo e sinal de veneração ao Santo.

Outro espaço simbólico que não carrega em si a sacralidade, mas é lugar de apreciação é o Zoológico São Francisco, iniciado em 1970, em razão da necessidade de alojar os animais trazidos pelos romeiros como presente aos frades franciscanos. Essa prática da doação de animais se associa com a biografia do Santo, o amor que sentia pelos animais era tanto que conversava e tratava-os com carinho, assim, como seus irmãos.

Símbolo da memória, o Museu Regional São Francisco ${ }^{19}$ dispõe de um acervo variado, adquirido por meio de doações tanto da comunidade, como da Igreja. Composto por peças sacras, hábitos, fotografias, pinturas ${ }^{20}$, conta com o primeiro cofre da Basílica; uma motocicleta alemã modelo 1938, o primeiro sino de Canindé; pias batismais e objetos que contam a história da devoção.

17 Salão reservado para recepção e exposição de ex-votos e outros objetos, construído em 1986 com este intuito (Informação contida no texto de WILLEKE OFM, Venâncio. São Francisco das Chagas de Canindé: resumo histórico. 2o edição. Canindé 1993. Petrópolis RJ: Ed. Vozes, 1973, p.50).

18 Retribuição simbólica da promessa. Não se limita ao pagamento da promessa como uma forma contratual entre Deus e o homem. A promessa leva à uma ação de sujeição e de retribuição pela graça alcançada.

19 Após os primeiros milagres concedidos por São Francisco das Chagas, começam a acontecer muitos deslocamentos dos romeiros dos mais diversos locais. Com isso, esses peregrinos deixam na cidade, além da fé ao Santo, peças que representam essa devoção.

20 Museu possuía aproximadamente 3.000 peças e atualmente conta mais de 5.000 peças. 
Imagética das imagens representado na Estátua de São Francisco ${ }^{21}$, localizada no bairro do Moinho, ponto mais alto da cidade de Canindé. A obra mede 30,25 metros, recebeu o título de maior imagem sacra do mundo, fruto da criação do artista plástico Deoclécio Soarez Diniz ${ }^{22}$. Orientação oficial da Igreja é que o culto da religião não se dirige às imagens em si mesma como realidade inalterável, mas em seu aspecto próprio capaz de conduzir o fiel a Deus e ao Santo de Veneração.

As Fitas de São Francisco da Chagas representam a materialidade da fé. Os devotos acreditam que, se usá-las até quebrar, seus pedidos serão realizados. As fitas são amarrados junto à Estátua, na Casa das Velas, na Basílica, nos retrovisores dos veículos, nos punhos dos devotos (ver imagem 04).

\section{Imagem 04 - Devoções das Fitinhas}

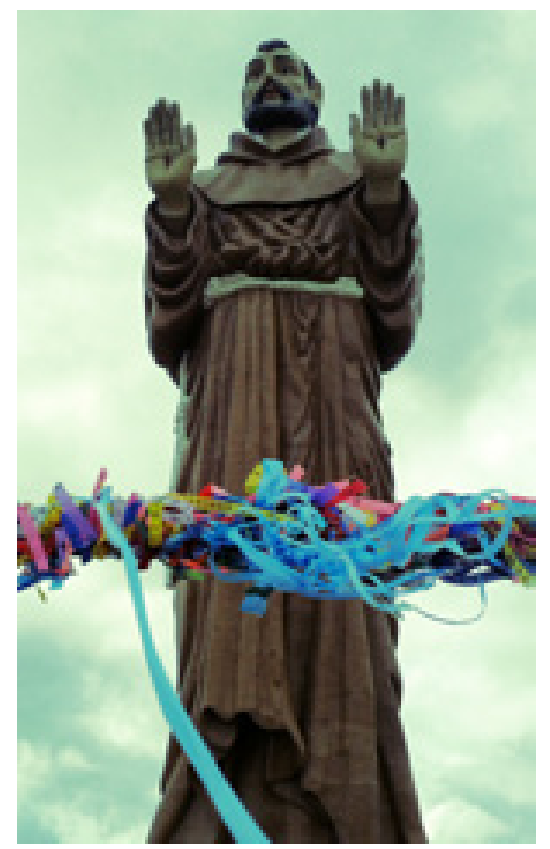

Fonte: Ivo Silva, 2014

Outro registro da imagética é o Painel de São Francisco ${ }^{23}$, segue arrastando multidões de fieis que depositam sua fé na representação do Santo.O andor deixa a Casa

21 Os monumentos são entendidos como forma simbólica de representações e que, por sua vez, compõem os espaços. São impregnados de significados e simbolismo, podendo conter significados variáveis na memória.

22 Escultor conhecido como Bibi, recebeu, em 2004, da Secretaria de Cultura do Estado do Ceará, o título de "Tesouro Vivo" da arte e cultura cearense. Atualmente continua a desenvolver trabalhos em mármore, fibra de vidro e outros materiais.

23 Andor foi criado no dia 10 de julho de 1890, pelo padre Manoel Cordeiro da Cruz, confeccionada no Estado da Bahia e sua estampa de origem italiana. A abertura da festa inicia por volta das $4 \mathrm{~h}$ da manhã com hasteamento da bandeira e celebração eucarística. Segue durante dez dias com celebrações religiosas, na Praça dos Romeiros. Procissões com o Painel e a Imagem de São Francisco, saindo da Basílica à Praça dos Romeiros, retornando após a novena para a Basílica. 
dos Milagres três vezes ao ano, no dia de 2/08 quando a Igreja comemora o Perdão de Assis ${ }^{24}$; no dia 17/09 data em que se celebram as Chagas de São Francisco, e a terceira na festa de São Francisco (24/09 a 04/10) ${ }^{25}$.

A Bandeira de São Francisco ${ }^{26}$ é hasteada nos ritos iniciais da festa e descerrada no último dia da novena, trafega pelas ruas, e durante sua travessia os fiéis arremessam moedas junto a bandeira como forma de gratidão pelas graças recebidas. Uma prática alterada, nos últimos anos, é a disputa pela bandeira. No final dos festejos, os fiéis se aglomeram junto ao mastro, na expectativa do descerramento levar um pedaço da bandeira consigo.

A experiência do devoto com o Santo se amplia e se revela no espaço, na sacralidade do lugar, porque é nesse local que ocorrem o encontro com a divindade. As peregrinações abordam os anseios do devoto diante da integração com a divindade e da salvação. As romarias estão associadas a penitência e obtenção da graça. Muitos refazem a pé no Caminhos de Assis, um trecho de $136 \mathrm{~km}$ de estrada ligando as cidade de Maranguape, Caridade e Canindé. No percurso instalações físicas para repouso diurno/ pernoite e sanitários dão um pouco de conforto necessário na caminhada espiritual.

Na Via Sacra da Igreja do Monte, o exercício piedoso dos fieis que percorram os passos de Jesus, meditando à Paixão de Cristo. Os romeiros chegam a transportar pedras sobre a cabeça, permutando de uma estação à outra. Ao final da caminhada, chega-se à Igreja do Monte, dedicada a Cristo Rei. No total são 14 estações dispostos ao longo da via ${ }^{27}$ que retratam a aflição de Cristo.

A religiosidade em Canindé se amplia além dos muros do Santuário de São Francisco, através da carroceria do pau de arara (ver imagem 05); nos incontáveis mendicantes que se espalham na rodovia e nas ruas em busca pela oferta; e no desejo de pagar a promessa. Compreendemos a irradiação do sagrado na organização da viagem; na bênção do Santo estendidas à família na fotografia; na água benta que purifica e

24 Memória celebrada pela Família Franciscana e cuja ocasião se celebra Nossa Senhora dos Anjos da Porciúncula, uma pequena capela em que São Francisco apresentou especial benignidade. Foi nesse lugar dedicado a Nossa Senhora que teve inicio a Ordem dos Frades Menores e onde o santo de Assis atravessou seus últimos dias sobre a terra. São Francisco obteve do Papa uma nobre indulgência, que em seguida se estendeu a todas as igrejas. No dia 2 de agosto de cada ano (das 12 horas do dia 10 de agosto até as 24 horas do dia 2), pode-se adquirir a Indulgência Plenária, com as seguintes condições: 1) Visitar uma igreja paroquial, onde se reza o Credo, para alegar a identidade cristã; e o Pai Nosso, para afirmar a dignidade de filhos de Deus adquiridos no Batismo; 2) Confissão sacramental (oito dias antes ou depois); 3) participação na celebração eucarística e a comunhão.

25 Os devotos conduzem o Painel em procissão pela cidade em direção à Praça dos Romeiros, onde ocorre a novena de São Francisco das Chagas.

26 A bandeira do Município transporta consigo a influencia dos franciscanos na civilização. O desenho incide em um retângulo dividido horizontalmente em duas faixas, uma amarela e outra verde. No centro o brasão municipal. Na parte esquerda, duas mãos cruzadas, ambas com chagas. As mãos cruzadas simulam Jesus, crucificado, e São Francisco de Assis, estigmatizado. Este símbolo representa a intensa religiosidade presente no Município.

27 Os romeiros vão chegando à Avenida Chico Campos, ao lado da Igreja de Nossa Senhora das Dores, para iniciar o primeiro ato de fé do dia. 
renova as forças daqueles que acreditam; no momento da elevação das chaves de suas residências; na vela acessa durante às procissão; nas pedras da Via Crucis; no tocar da imagem; no entoar dos hinos e revoada dos sinos; na disposição dos ex votos; no pedido de retorno para casa e no pedido de regresso do ano seguinte.

As devoções tanto na órbita da religiosidade popular quanto no rito oficial estão sujeitas à continuidades e rupturas. A religiosidade popular é itinerante, impulsiona as pessoas ao deslocamento, a visitar santuários, relíquias, templos. Assim, reconhecendo a presença do sincretismo religioso.



Fonte: Francelino Alves, 2016

Pelas Promessas, ressalvamos os acontecimentos ditos extraordinários que, à luz dos sentidos da transgressão das leis naturais, em Canindé, associados a intercessão de São Francisco das Chagas, quando os alcançam, saldam nas mais diversas formas, como doações de roupas, corte de cabelo, ex votos representados na forma de membros humanos, dízimo, fotografias, mortalhas, gêneros alimentícios, caminham de pés descalços, ajoelham-se na igreja, contornam na mesma posição os monumentos religiosos, osculam as imagens sacras dentro dos templos, entoam os cantos ao Santo Seráfico.

Os romeiros buscam uma experiência mística, um contato que transcende as pinturas da fé. Os pagadores de promessas se acham eternos devedores da graça. No 
lugar sagrado coabitam a "sacralidade eclesiástico-institucional e devocional popular". Percebemos a transversalidade da fé; o pagamento da promessa para si e para terceiros (familiares/amigos); sacralidade presente na cidade por meio das ruas, imagens, igrejas, mas também na fé em particular de cada devoto, na partilha do pão, na prece e no riso.

\section{CONSIDERAÇÕES FINAIS}

Este ensaio tenta se aproximar de uma descrição primária da religiosidade popular e da imagéticas das devoções. A experiência simbólica passa pelo olhar, manifestações e formas. $\mathrm{O}$ sagrado é acessível ao homem isso porque de certa forma simbólica está também no seu inconsciente.

A história de São Francisco de Assis é ladeada de narrativas surpreendentes, essas e tantas outras histórias de milagres representados nas peças, fotografias, memória, canções, romarias, em cada pedaço de chão desse solo. Nenhuma expressão simbólica do sagrado é desgarrada de compreensão. Com efeito, todas as manifestações revelam um significado que transcende o entendimento racional. Portanto, em vez de tomar o sagrado como algo meramente ilusório, aquele que pratica o encara como algo real, permanente e pertinente ao mundo. Entendemos que o homem não tem, fundamentalmente, que compreender todo o significado estrutural de um símbolo, para absorvê-lo como símbolo, pois cada consciente capta a informação em um nível inconsciente imediato.

\section{REFERÊNCIAS}

AUGRAS, Monique. Todos os santos são bem-vindos. Rio de Janeiro: Pallas, 2005.

AUMONT, Jacques. A imagem. 2ed. Campinas: Papirus, 1995

AZZI, Riolando. Elementos para a história do catolicismo popular. Revista Eclesiástica Brasileira, Petrópolis, v.36, n.141, p.82-114, mar.1978.

BRITO, Ênio José da Costa; GORGULHO, Gilberto da Silva (org.). Religião ano 2000. São Paulo: CRE - PUC - SP/Loyola, 1998.

BOFF, Leonardo. O pensar sacramental. Eclesiástica Brasileira. 35. Petrópolis, RJ, 1976

DELEUZE, Gilles. Diferença e repetição. Rio de Janeiro: Graal, 1988.

DURKHEIM, Emile. As formas elementares da vida religiosa. São Paulo: Paulus, 1989. 
ELIADE, Mircea. Tratado de História das Religiões. 2ª ed. São Paulo: Martins Fontes, 2001. FRANCASTEL, Pierre. A realidade figurativa. 2. ed. São Paulo: perspectiva, 1993.

GÓIS. João de Deus. Religiosidade Popular Pesquisas. Edições Loyola, São Paulo, 2009. HOONAERT, Eduardo. A cristandade durante a primeira época colonial. In: HOONAERT, Eduard et al. História da igreja no Brasil: ensaio de interpretação a partir do povo. 3 ed. São Paulo: Paulinas: Vozes, 1983. Tomo II/l.

Larrañaga, Ignacio. O irmão de Assis. 20 ed. São Paulo: Paulinas. 496 p.

LOPES, José Rogério. A imagética da devoção. A Iconografia popular como mediação entre a consciência da realidade e o Ethos religioso. UFRGS Editora. Porto Alegre: Rio Grande do Sul, 2010.

QUAINI, M. Marxismo e geografia. Rio de Janeiro: Paz e Terra, 1979.

MALDONADO, L. Religiosidades Populares. Concilium, n. 206, 1986.

MERLEAU-PONTY, M. A fenomenologia da percepção. Rio de janeiro: Freitas Bastos, 1971.

MOREIRA, Ruy. Geografia e Práxis. A presença do espaço na teoria e na prática geográficas. São Paulo: contexto 2012.

OLIVEIRA. Christian Dennys Monteiro de. Geografia do Turismo na cultura carnavalesca: O sambódromo do Anhembi. São Paulo: Paulistana, 2007.

OLIVEIRA. Marcelo João Soares de. A PEREGRINAÇÃO E SEUS ENIGMAS: O desvendamento no encontro do devoto com o "santo vivo" rumo ao santuário de São Francisco do Canindé. Doutorado em Ciências da religião. Pontifícia Universidade Católica de São Paulo. PUC. São Paulo-SP, 2011.

ROSENDAHL, Zeny. Hierópolis: o sagrado e o urbano. Rio de Janeiro: EdUERJ. 1999. . Uma proposta temática. In: MENDONÇA, Francisco \& KOZEL, Salete (org). Elementos de Epistemologia da Geografia Contemporânea. Curitiba: Editora da UFPR, 2002.

SANTOS, Milton. por uma geografia nova: da crítica da geografia a uma geografia crítica. São Paulo: Hucitec:Edusp, 1978.

TUAN, Yi-Fu. Espaço e lugar. São Paulo: Difel, 1983.

TURNER, Victor. O processo ritual: estrutura e anti-estrutura. Petrópolis: Vozes, 1974. 